\title{
A Mosaic of Vigna repens in Puerto Rico
}

\section{J. Enrique Pérez and Julio Bì̀d' \\ INTRODUCTION}

Vigna repens is a common weed in Puerto Rico often found growing in humid shaded places, in thickets and roadsides at lower elevations. ${ }^{2}$ This weed is infected frequently by a virus which generally induces leaf distortion and oak-leaf pattern mosaic (fig 1). The following investigations were conducted on the characters of this virus because of its potential for injury to economic crops.

\section{MATERIALS AND METHODS}

Diseased leaves were collected from a field at Cupey Alto and from areas neighboring the Agricultural Experiment Station at Río Piedras. For inoculation tests, leaves showing marked symptoms of disease were ground in a meat chopper and the pulp squeezed through a double layer of gauze. The extracted crude sap was inoculated onto either the cotyledons or primary leaves of test plants. Inoculated leaves were rinsed immediately with tap water. The plants used for virus recovery tests were Chenopodium amaranticolor and C. quinoa.

\section{PHYSICAL PIROPEIRTIES}

\section{Inactivation Test}

For studies of the dilution endpoint and thermal inactivation, extracts were obtained as described. Serological tubes of the Kahn type were used for thermal inactivation tests. Five sero-utility baths containing distilled water were set at the following temperatures: $45^{\circ}, 50^{\circ}, 55^{\circ}, 60^{\circ}$ and $65^{\circ} \mathrm{C}$. to test the thermal resistance of the virus. The tubes were filled with sap, ('apped, and immersed simultaneously in the corresponding bath for 10 minutes, then quickly removed and cooled in iced water. The sap from each treatment was inoculated onto leaves of Chenopodium amaranticolor, which proved in preliminary trials to be an excellent indicator host. Infectivity of untreated inoculum also was tested on this host. Results were recorded 6 and 12 days after inoculation.

'Bacteriologist and Director, Department of Plant Pathology and Botany, respectively, Agricultural Experiment Station, Mayagüez Campus, University of Puerto Rico, Río Piedras, P.R.

2 Britton, N. L., Scientific Survey of Porto Rico and the Virgin Islands, Vol. 5, Botany of Porto Rieo and the Virgin Islands, New York Academy of Sciences, p. 424,1924 . 


\section{Dilution Endpoint}

For the dilution endpoint test, sap was extracted as noted above and diluted in tenfold steps in $0.01 \mathrm{M}$ phosphate buffer $\mathrm{pH}$ 7.0. Sap diluted from $1 / 10$ to $1 / 100,000$ was rubbed onto three leaves of $C$. amaranticolor plants. Results were recorded 6 and 12 days after inoculation.

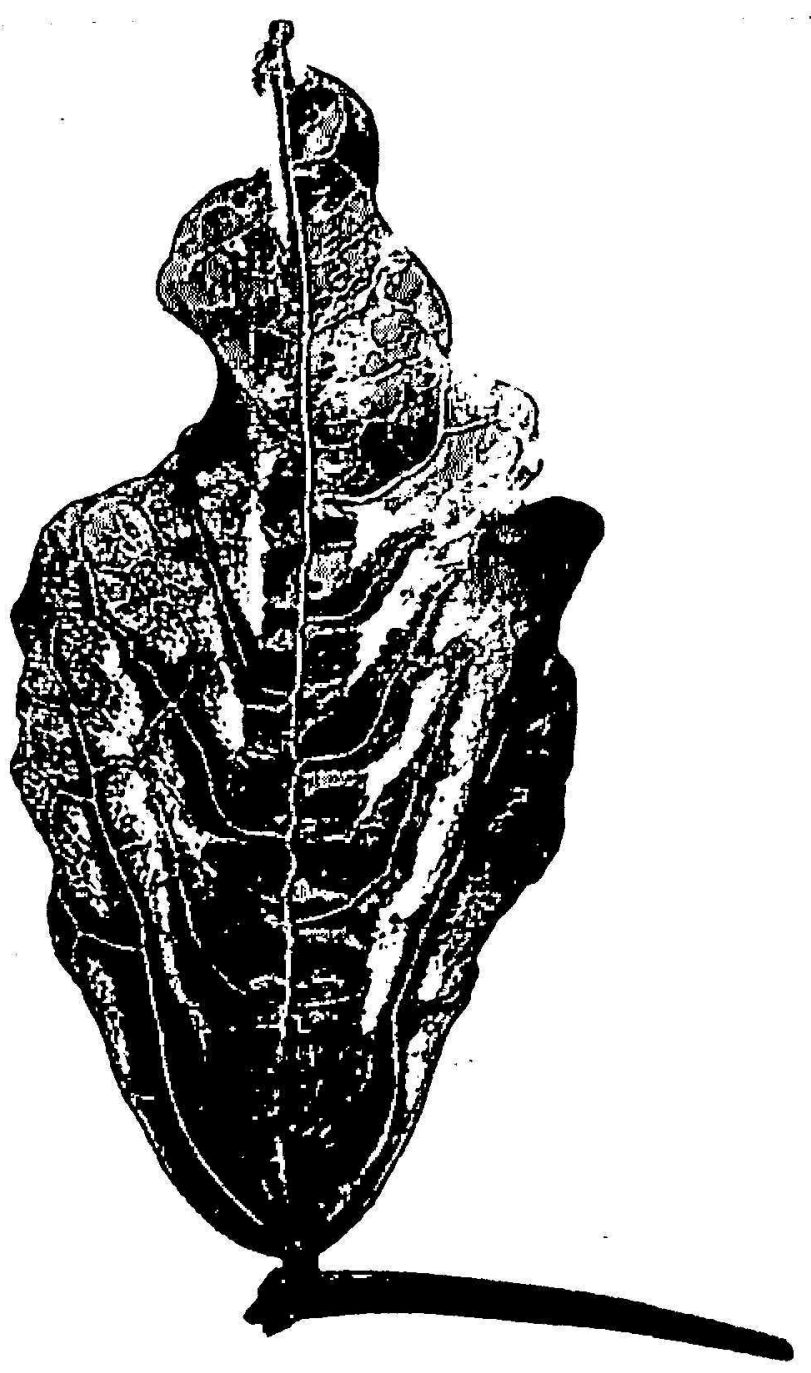

Fici. 1. - Leaflet from a trifoliate leaf showing the oak-leaf pattern mosaic of Vigna repens.

Stability of the Virus in the Frozen State

Stability in the frozen state was tested by distributing crude sap from mosaic affected leaves in aliquots in plastic tubes fitted with rubber stoppers and placed in a freezer at approximately $-25^{\circ} \mathrm{C}$. A portion of sap was thawed twice, then refrozen and tested sis days later. Other portions were left untouched for still later testing. 


\section{RESULTS \\ HOST RANGE}

The virus was inoculated on six or more plants of 45 species in seven families. The species of plants inoculated and their reaction to such inoculation follows.

\section{Susceptible Species}

Chenopodiaceas.-Chenopodium amaranticolor, local chlorotic lesions which became necrotic in about 9 days. Chenopodium quinoa, local chlorotic lesions of the same pattern but larger (about $4 \mathrm{~mm}$. in diameter) (fig. 2).

LEGUMinosat.-Vigna sinensis Endl. var. Blackeye developed net necrosis of the veins on primary leaves, also small necrotic spots alongside the veins but the virus did not become systemic. This was observed in only $2 / 25$ inoculated plants. On Vigna repens $2 / 104$ plants showed characteristic mosaic symptoms. On Vigna parviflora 1/6 plants developed mosaic with distortion of non-inoculated leaves.

Phaseolus vulgaris var. Blanca del País-developed necrotic vein netting in several separate spots on primary leaves, followed by death of trifoliates. Variety Rosita—numerous necrotic local lesions on primary leaves. Var. Dominicana-epinasty of primary leaves and inward cupping of first trifoliates. The plants died in 12 days. Var. Criolla-veinal necrosis of primary leaves. Var. Bonita-epinasty of primary leaves and inward cupping of first trifoliates; some plants were killed. Var. Marca Diablo-patches of veinal necrosis on primary leaves. Selections: Greenpod BBL 235-veinal necrosis on primary leaves; Early Gallatin-necrotic patches on primary leaves; Bon Verte-necrotic patches on primary leaves; Greenpod 64473veinal necrosis of primary leaves; Greenpod 64488-few necrotic dots on primary leaves; Greenpod 64492-necrotic dots on primary leaves followed by net necrosis of veins but limited to patches; Greenpod BBI 206necrotic spots on primary leaves; Greenpod BBL 235-6-veinal necrosis on primary leaves; sometimes on first trifoliates; var. Lentucky Wonder Wax-numerous necrotic dots, later changing to reddish vein necrosis, all plants dead after 10 days; var. Charleroi-reaction same as for Kentucky Wonder Wax.

\section{Nonsusceptible Species}

AMARANTHACEA E.-Gomphrena globosa.

CHENOPODIACEA E.-Beta vulgaris var. LS 8; Chenopolium capilatum.

composita E--Lactuca salina J. var. Black Seeded Simpson; Zimmia elegans Jacc. 
cucurbitacea e.-Cucumber, Cucumis sativus L. var. Chicago Pickling, var. Black Diamond; Pumpkin, Cucurbila pepo L. var. Small Sugar.

GRAMINEA E.-Sorghum vulgare.

Leguminosat.-Cassia occidentalis; Phaseolus vulgaris selections Green

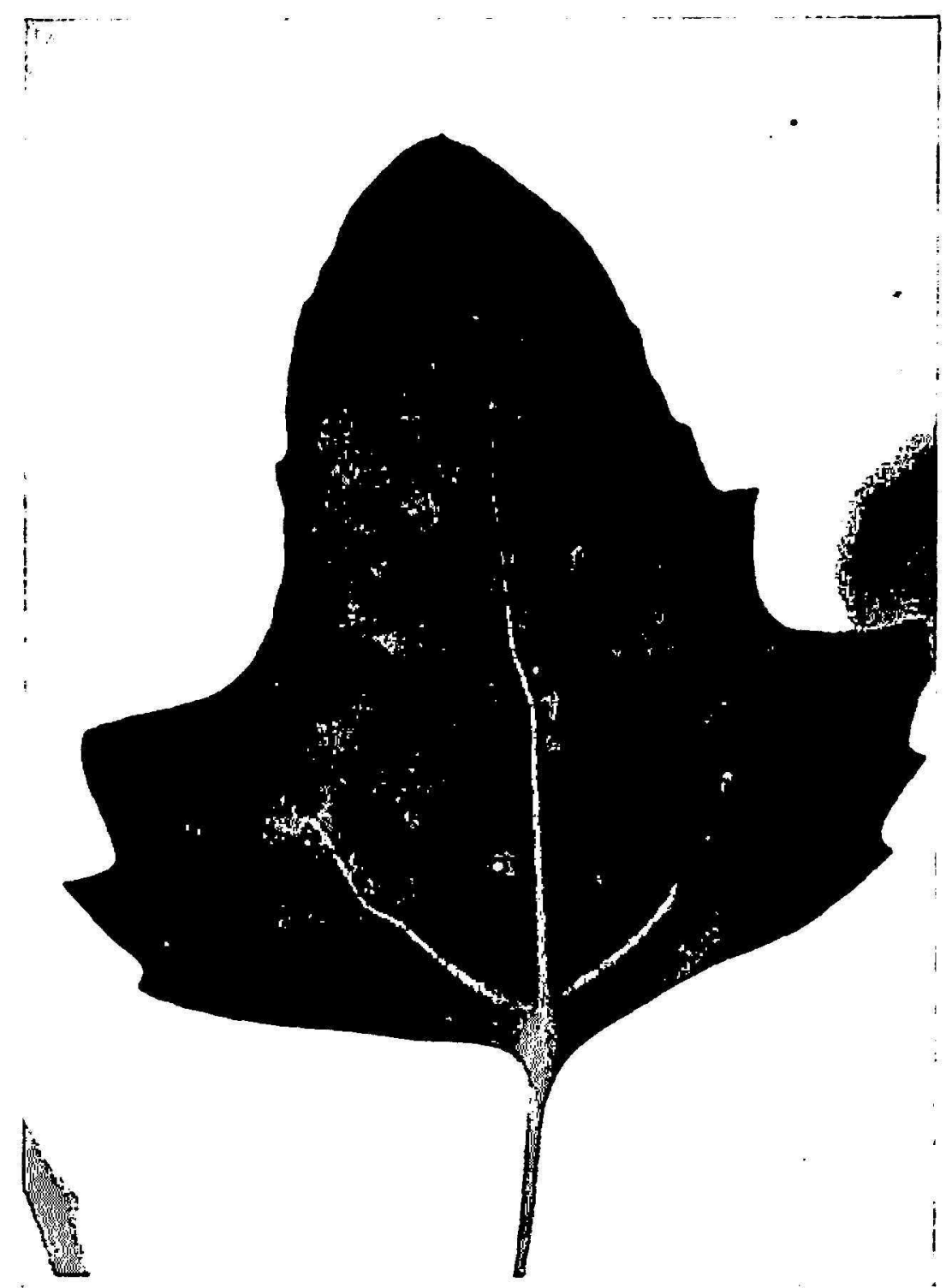

Fig. 2.--Jocal lesions produred on (henopolium quinoa by the Vigna repens virus. Photograph taken 7 days after inoculation.

Isle, Exp. No. 16, Greenpod 64478, 64489, and 65390; Phaseolus aureus; Pisum salinum var. Dwarf Telephone; soybean Glycine max L. Merr. var. Lee; Vigna sinensis Lindl. vars. Black and Clay; Vigna spp. a local smallseeded blackeye cultivar known as "Frijol del País"; Vigna cylindrica; I'igna sesquiperlalis; Vigna lancifolia; Vigna wilmsii; Vigna oblongifolia: Vigna da'yi; ligna verillala; Tigna membranaceae.

solanaceate-Pepper, Capsicum frutescens vars. Large Bell Hot and 
California Wonder; tobacco, Nicoliana tabacum L. (NN type), Nicotiana glutinosa L.; jimson weed, Datura stramonium L.

\section{PHYSICAL PROPERTIES}

\section{Inactivation Test}

The thermal resistance of the virus was found to be between $55^{\circ}$ and $60^{\circ}$ C. in replicated experiments. This virus thus is inactivated upon exposure to 10 minutes at such temperatures.

\section{Dilution Endpoint}

The virus produced local lesions on $C$. amaranticolor and $C$. quinoa plants at dilution to $1 / 1,000$ but was not infectious at $1 / 10.000$ dilution.

\section{Stability in the Frozen State}

Infective sap thawed twice, as described above, was found to be noninfectious after 83 days freezing; that kept frozen and left undisturbed was infectious after 117 days, the longest period frozen preparations were tested. Positive transmission was demonstrated by the appearance of characteristic chlorotic lesions in the leaves of $C$. amaranticolor and $C$. quinoa which were inoculated at the same time.

\section{DISCussion}

This report appears to be the first concerning a mosaic on Vigna repens. This virus induced a variety of symptoms in susceptible Leguminosae. Some plant species developed symptoms consisting of 1 , veinal necrosis or necrotic patches on the primary leaves: Vigna sinensis var. Blackeye and bean selections Greenpod BBL 235, Early Gallatin, Bon Verte, Greenpod 64473, Greenpod 64492, Greenpod BBI, 235-6, varieties Criolla and IIarca Diablo; 2, necrosis followed by death of the plant: Phaseolus vulgaris vars. Blanca del País, Kentucky Wonder Wax and Charleroi; 3, necrotic dots or spots on primary leaves: $P$. vulgaris vars. Rosita, selections Greenpod 64488 and Greenpod BBL $206 ; 4$, epinasty of primary leaves followed by inward cupping of trifoliates and death: $P$. vulgaris vars. Dominicana and Bonita.

Only one additional species of the genus Vigna (Vigna parviflora), other than the natural field host, was found to be susceptible when inoculated by mechanical means. It was rather surprising to find that the virus was transmitted to its natural host with difficulty. This perhaps is an indication that it may be insect-borne in nature. Two plants outside of the Leguminosae, Chenopodium quinoa and C. amaranticolor, proved to be excellent local-lesion indicators for the Vigna virus. 
The possible relationships between the Vigna repens virus and a recently found aphid transmitted virus of Rhynchosia hosei are under investigation.

\section{SUMMARY}

A new mosaic virus found in Vigna repens is described. The virus was transmitted mechanically to several varieties of Phaseolus vulgaris and to Vigna parviflora but failed to infect other species of Vigna tested. The virus was transmitted to its own natural host Vigna repens with difficulty.

\section{RESUMEN}

Se describe un nuevo virus que produce un mosaico en las hojas del yerbajo Vigna repens. El virus se puede transmitir por inoculación mecánica a algunas variedades o selecciones de Phaseolus vulgaris mientras que otras variedades y selecciones de Vigna spp. mostraron resistencia. También se transmite a la Vigna parviflora y con dificultad a la planta original (Vigna repens) de la cual se aisló. 